\title{
The Combination Between Some Medical Oils Antibiotics and Its Effect on Some Pathogenic Microorganisms
}

\author{
M.M.Hazaa, M.O.Abdel-Monem, I.M.Abdel-Aziz and E.A.Mohamed \\ Botany \& Microbiology Dept ., Faculty of Science , Benha Univ, Faculty of Science, Benha Univ., Benha, Egypt \\ E-Mail: E.Abdalla @gmail.com
}

\section{Abstract}

For many years, the battle between humans continues and the multiplicity of infections and disease-causing diseases. Emerging on the battlefield as one of the most important challenges facing human health is bacterial resistance and its rapid rise. These have become a major global public health concern revitalizing the need for new antimicrobial compounds. A rational approach to dealing with problems of antibiotic resistance requires detailed knowledge of the various biological and non-biological factors that influence the rate and extent of resistance development. A combination therapy combining traditional antibiotics and essential oils is currently blooming and represents a potential area for future investigations. This new generation of phytopharmaceutical may shed light on the development of novel drug regimens in the fight against antibiotic resistance. This review reinforced and described the results of observed synergies between essential oils and antibiotics, and highlighted the potential of essential oils as a potential resistance modifying agent. The aim of this thesis is to verify whether the bio-reactivity of medicinal oils can be assessed using microorganisms in standard and clinical testing and their sensitivity to specific antibiotics. The bacteria which produce antibiotics must themselves be resistant to those antibiotics or they would kill themselves. Other bacteria can also become resistant to the antibiotics if they are exposed to the antibiotics for long periods or at concentrations that are not adequate to kill the microorganisms immediately [1]. Disease producing bacteria which infect humans and are resistant to one, or multiple, antibiotics are a serious problem for health care in many parts of the world. For this reason, new antibiotics must be discovered, approved, and made available for medical use continuously. The study was performed on 5 isolated bacterial samples from different medical laboratories and one samble from yeast. These samples were tested bacteriologically and the samples were grown under ideal conditions under anaerobic and anaerobic conditions. The ability of eight natural lemon oils with different antibiotics to kill antibiotic-resistant bacteria, which are onion, garlic, watercress, rosemary, thyme, parsley, mint and cinnamon, were tested with the following antibiotics, vancomycin, chloramphenicol, ofloxacin, ampicillin, amoxicillin, moxifloxacin, ampicillin, amoxicillin, and trafloxacin. The results showed that E. coli bacteria are very sensitive to all oils in the case of all antibiotics, especially parsley oil, which is the most efficient oil in affecting the isolated bacteria. and Identification was confirmed for isolates Candida albicans strain, Escherichia coli, Klebsiella pneumoniae, Pseudomonas aeruginosa, Staphylococcus aureus and Streptococcus pyogenes. The most resistant to antibiotics after making molecular studies by studying its genetic sequence and it was registered in the International Genebank.

\section{Introduction}

Microbiology is the study of microorganisms, which are unicellular and are seen only under a microscope. This includes prokaryotes like viruses and eukaryotes like certain algae, fungi, and protozoans. Microbiology is a branch of biology and deals with much sub-branches-like Virology, Bacteriology, Mycology, and Parasitology

More than half of our antibiotics are produced by species of Streptomyces. They are filamentous bacteria that commonly inhabit the soil. Few antibiotics are produced by molds, mostly of the genera Penicillium and cephalosporins. With the advent of organic chemistry, many antibiotics are now obtained by chemical synthesis. Sulfa drugs are synthetic.

\section{Mechanisms of action and resistance of antibiotics}

The mechanism of action of antimicrobial agents can be categorized based on the function that is affected by the agents, these generally included the following: inhibition of the cell wall synthesis, or nucleic acid synthesis, inhibition of ribosome function, or cell membrane function and inhibition of folate metabolism.

\section{Antibiotic Resistance \\ Antibiotic resistance is the ability of bacteria or other microbes to} resist the effects of an antibiotic Fig (1). Antibiotic resistance occurs when bacteria change in some way that reduces or eliminates the effectiveness of drugs [4].

The bacteria survive and continue to multiply causing more harm. It is a specific type of drug resistance. The emergence of bacterial strains that are resistant to current antibiotics is an important public health concern. Antibiotic resistance evolves naturally via natural selection through random mutation. Once such a gene is generated, bacteria can then horizontally transfer the genetic information (between individuals) by plasmid exchange. If a bacterium carries several resistance genes, it is called multi-resistant. 


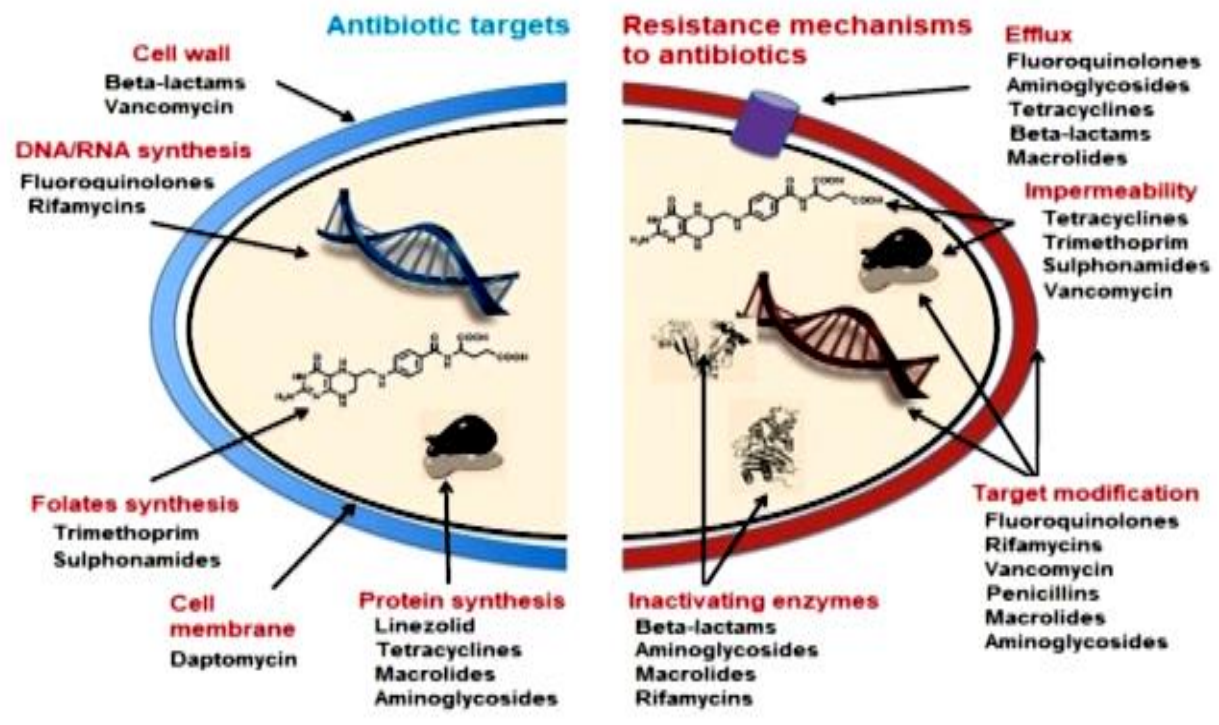

Fig (1) Antibiotic resistance.

\section{Materials and methods}

This study was conducted on different bacterial samples resistant to different types of antibiotics. The samples were collected from different clinical labs. Study was done from November, 2019 till July, 2020.

\subsection{Sample collection and processing}

The specimens were collected and transported according to (Murray et al., 2007) under aseptic conditions directly to the

Microbiology Laboratory at Clinical department Genetic Engineering Research Department (VACSERA) (Cairo, Egypt) where the study was carried out.

\subsection{Isolation and cultivation of bacteria}

A $1 \mathrm{~cm} 2$ area of clinical samples was collected with a sterile loop of and then inserted into broth tube as transport media. The contents were collected under complete aseptic condition. Samples were cultured:

Bacterial isolates: samples were inoculated on Trypticase soya agar plate for $24 \mathrm{hrs}$ at $37^{\circ} \mathrm{C}$.

Yeast isolates: samples were inoculated on Sabroud dextrose agar plate for $48 \mathrm{hrs}$ at $28^{\circ}$ C. 3.3 . Media used for Isolation and cultivation of bacteria:

Trypticase soya agar [5].

Tryptic Soy Agar is used as a general growth medium for the isolation and cultivation of microorganisms. They are general-purpose, nonselective media providing enough nutrients to allow for a wide variety of microorganisms to grow. This medium is also recommended for use in the cultivation, storage, maintenance and transportation of pure cultures of microorganisms. $17 \mathrm{gm}$ pancreatic digest of casin , $3 \mathrm{gm}$ papaic digest of soyabean meal, sodium chloride $5 \mathrm{gm}$, dextrose $2.5 \mathrm{gm}, 2.5$ dipotasium hydrogen phosphate and $15 \mathrm{gm}$ agar were suspended in one liter of distilled water then dissolved and boiled. Autoclave at $121{ }^{\circ} \mathrm{C}$ for $15 \mathrm{~min}$, cool to $40-50{ }^{\circ} \mathrm{C}$ then added $5 \%$ blood were added under sterile condition. $\mathrm{PH}$ was adjusted to $7.3 \pm 0.2$ at $25 \mathrm{oC}$ by using $0.1 \mathrm{~N} \mathrm{HCl}$ or $0.1 \mathrm{~N} \mathrm{NaOH}$ before sterilization.

\section{Sabroud dextrose agar}

Sabouraud Dextrose Agar (SDA) is used for the isolation, cultivation, and maintenance of nonpathogenic and pathogenic species of fungi and yeasts. SDA was formulated by Sabouraud in 1892 for culturing dermatophytes. The $\mathrm{pH}$ is adjusted to approximately 5.6 in order to enhance the growth of fungi, especially dermatophytes, and to slightly inhibit bacterial growth in clinical specimens.

$40 \mathrm{gm}$ dextrose, $10 \mathrm{gm}$ peptone and $15 \mathrm{gm}$ agar were suspended in one liter of distilled water then dissolved and boiled. Autoclave at $121{ }^{\circ} \mathrm{C}$ for $15 \mathrm{~min}$, cool to $40-50{ }^{\circ} \mathrm{C}$ then added $5 \%$ blood were added under sterile condition. PH was adjusted to $5.6 \pm 0.2$ at $25^{\circ} \mathrm{C}$ by using $0.1 \mathrm{~N} \mathrm{HCl}$ or $0.1 \mathrm{~N} \mathrm{NaOH}$ before sterilization.

\subsection{Identification of bacterial isolates}

Bacterial isolates were identified according to Bergey's Manual of determinative bacteriology.

\section{The colonies morphology}

Colony size, shape, whether it is opaque or translucent, mucoid or dry production of characteristic colony color or any change in the color of the agar.

\section{Microscopic examination}

To differentiate between Gram-positive (purple or violet color) and Gram-negative (red or pink color). A heat fixed smear from 18-24 hrs bacterial culture was prepared on a clean slide. Smears were stained with crystal violet solution for $30 \mathrm{sec}$, and then 
washed with distilled water. The prepared smear was covered with Gram's iodine solution for $10 \mathrm{sec}$.

The iodine was poured off and slide was washed with a decolorized (mixture of ethanol and acetone 95 $\%)$ until no more purple stain runs from the slide (10$20 \mathrm{sec}$ ). The slide was gently washed with distilled water, then stained with counter stain (safranin) for $30 \mathrm{sec}$, then washed with distilled water and blot dry. The dried slides were microscopically examined under the oil immersion lens.

\subsection{S rRNA/ 18S rRNA genessequencing}

Partial 16S rRNA gene sequencing was used to confirm the biochemical identification.

Universal 16s rRNA primers $27 \mathrm{f}$ (5'AGAGTTTGATCMTGGCTCAG-3').

\section{Molecular identification of the isolate strains}

The identification of the most resistant and frequent strain, Staphylococcus epidermidis and staphylococcus aureus, ............... were confirmed by investigation of $16 \mathrm{~S} r$ RNA gene sequences using a 310 genetic analyzer sequencer. Selected Bacterial DNA was extracted using GenEluteTM Bacterial Genomic DNA Kit (Sigma Aldrich) as per manufacturer protocol. Amplicons of 16S rRNA were sequenced in (VACSERA) Egypt, using a 310 genetic DNA Sequencer (Genetic Analyzer, Applied Biosystems, USA).

\section{Chemicals and reagents}

All reagents used were of analytical grade. PCR and sequencing chemicals, molecular biology kits used were purchased from (Local supplier).

\section{Extraction and purification of bacterial genomic DNA}

The DNA of the selected bacteria were extracted using GenEluteTM Bacterial Genomic DNA Kit, Sigma Aldrich as per manufacturer protocol and can be summarized as following: After $24 \mathrm{~h}$ growth at 37 ${ }^{\circ} \mathrm{C}$ on LB media, bacterial cells were centrifuged for $10 \mathrm{~min}$ at $12000 \mathrm{rpm}$ at $4^{\circ} \mathrm{C}$. The supernatant (growth medium) was discarded and the bacterial pellet was resuspended in $400 \mu \mathrm{L}$ of lysis buffer containing $50 \mu \mathrm{L}$ of lysozyme and $25 \mu \mathrm{L}$ of RNase then, incubation at $37^{\circ} \mathrm{C}$ for $15 \mathrm{~min}$. With careful shaking. $50 \mu \mathrm{L}$ of $20 \%$ lauroylsarcosine was added to the lysates, kept on ice for $5 \mathrm{~min}$ to obtain a translucent material.

\section{Results}

\section{Screening of antibacterial activities of different} essential oils

The antimicrobial activity of a selection of eleven Egyptian essential oils against the isolated bacteria was investigated and the results are summarized in Tables (1-6). Over and done with this experiment eight essential oils were nominated for carrying out the antimicrobial susceptibility test by Cinnamon Oil, Rosemary Oil, Thyme Oil, Parsley Oil, Onion Oil, Garlic Oil, Arugula oil, and mint oil along with different antibiotic against all tested bacterial species Fig (1) and Sch (1).

Table (1) Antimicrobial activity of different essential oils on the isolated bacteria vs. Chloramphenicol antibiotic.

\begin{tabular}{lcccccc}
\hline Bacteria & $\begin{array}{c}\text { E. } \\
\text { OSE }\end{array}$ & $\begin{array}{c}\text { Staph. } \\
\text { aureus }\end{array}$ & $\begin{array}{c}\text { Pseudomonas } \\
\text { sp. }\end{array}$ & $\begin{array}{c}\text { Streptococcus } \\
\text { sp. }\end{array}$ & $\begin{array}{c}\text { Klebsiella } \\
\text { sp. }\end{array}$ & $\begin{array}{c}\text { Candida } \\
\text { albicans }\end{array}$ \\
\hline Control & 21 & 25 & 20 & 22 & 30 & 24 \\
Onion & 24 & 26 & 25 & 23 & 31 & 27 \\
Garlic & 24 & 27 & 24 & 22 & 25 & 25 \\
Arugala & 23 & 27 & 26 & 24 & 32 & 26 \\
Rosemary & 24 & 25 & 25 & 20 & 28 & 25 \\
Thyme & 22 & 26 & 25 & 21 & 31 & 26 \\
Parsley & 22 & 28 & 25 & 20 & 32 & 24 \\
Mint & 23 & 25 & 20 & 18 & 29 & 25 \\
Cinnamon & 25 & 26 & 24 & 22 & 28 & \\
\hline
\end{tabular}

Table (2) Antimicrobial activity of different essential oils on the isolated bacteria vs. OX antibiotic.

\begin{tabular}{lcccccc}
\hline $\begin{array}{l}\text { Bacteria } \\
\text { OSE }\end{array}$ & $\begin{array}{c}\text { E. } \\
\text { coli }\end{array}$ & $\begin{array}{c}\text { Staph. } \\
\text { aureus }\end{array}$ & $\begin{array}{c}\text { Pseudomonas } \\
\text { sp. }\end{array}$ & $\begin{array}{c}\text { Streptococcus } \\
\text { sp. }\end{array}$ & $\begin{array}{c}\text { Klebsiella } \\
\text { sp. }\end{array}$ & $\begin{array}{c}\text { Candida } \\
\text { albicans }\end{array}$ \\
\hline Control & 16 & 18 & - & 25 & - & - \\
Onion & 15 & 21 & - & 30 & -10 & 11 \\
Garlic & 16 & 22 & - & 25 & - & - \\
Arugala & 15 & 17 & - & 18 & - & - \\
Rosemary & 17 & 22 & - & 32 & - & -10 \\
Thyme & 12 & 17 & - & 30 & - & 10 \\
Parsley & 20 & 21 & - & 28 & - & - \\
Mint & 17 & 22 & - & 33 & & \\
Cinnamon & 17 & 20 & - & & & \\
\hline
\end{tabular}


Table (3) Antimicrobial activity of different essential oils on the isolated bacteria vs. trimethoprimsulfamethoxazole antibiotic.

\begin{tabular}{|c|c|c|c|c|c|c|}
\hline $\begin{array}{l}\text { Bacteria } \\
\text { OSE }\end{array}$ & E. coli & Staph. aureus & Pseudomonas sp. & Streptococcus sp. & Klebsiella sp. & Candida albicans \\
\hline Control & 22 & 14 & & & 20 & 18 \\
\hline Onion & 28 & . & & & 32 & 25 \\
\hline Garlic & 28 & 25 & & & 27 & 27 \\
\hline Arugala & 28 & & & & 25 & 25 \\
\hline Rosemary & 35 & & & & 25 & 30 \\
\hline Thyme & 25 & & & & 30 & 25 \\
\hline Parsley & 26 & & & & 24 & 25 \\
\hline Mint & 30 & & 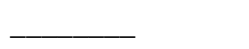 & $\ldots$ & 28 & 25 \\
\hline Cinnamon & 27 & 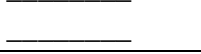 & $\bar{L}$ & $\bar{L}$ & 31 & 26 \\
\hline
\end{tabular}

Table (4) Antimicrobial activity of different essential oils on the isolated bacteria vs. Ampicillin antibiotic.

\begin{tabular}{|c|c|c|c|c|c|c|}
\hline $\begin{array}{l}\text { Bacteria } \\
\text { OSE }\end{array}$ & $\begin{array}{l}\text { E. } \\
\text { coli }\end{array}$ & $\begin{array}{l}\text { Staph. } \\
\text { aureus }\end{array}$ & $\begin{array}{l}\text { Pseudomonas } \\
\text { sp. }\end{array}$ & $\begin{array}{l}\text { Streptococcus } \\
\text { sp. }\end{array}$ & $\begin{array}{l}\text { Klebsiella } \\
\text { sp. }\end{array}$ & $\begin{array}{l}\text { Candida } \\
\text { albicans }\end{array}$ \\
\hline Control & 31 & 20 & & & & \\
\hline Onion & 27 & 13 & & & & \\
\hline Garlic & 28 & 14 & & & 11 & 12 \\
\hline Arugala & 25 & 13 & & & & \\
\hline Rosemary & 28 & 20 & & & & \\
\hline Thyme & 29 & 15 & & & & \\
\hline Parsley & 30 & 14 & & & & \\
\hline Mint & 28 & 17 & & & & \\
\hline Cinnamon & 28 & 15 & & & & 15 \\
\hline
\end{tabular}

Table (5) Antimicrobial activity of different essential oils on the isolated bacteria vs. Norfloxacin antibiotic.

\begin{tabular}{lcccccc}
\hline $\begin{array}{l}\text { Bacteria } \\
\text { OSE }\end{array}$ & $\begin{array}{c}\text { E. } \\
\text { coli }\end{array}$ & $\begin{array}{c}\text { Staph. } \\
\text { aureus }\end{array}$ & $\begin{array}{c}\text { Pseudomonas } \\
\text { sp. }\end{array}$ & $\begin{array}{c}\text { Streptococcus } \\
\text { sp. }\end{array}$ & $\begin{array}{c}\text { Klebsiella } \\
\text { sp. }\end{array}$ & $\begin{array}{c}\text { Candida } \\
\text { albicans }\end{array}$ \\
\hline Control & 22 & 23 & 24 & 25 & 28 & 23 \\
Onion & 30 & 24 & 28 & 25 & 26 & 28 \\
Garlic & 28 & 26 & 25 & 26 & 26 & 27 \\
Arugala & 24 & 25 & 30 & 30 & 30 & 30 \\
Rosemary & 30 & 25 & 25 & 24 & 28 & 28 \\
Thyme & 26 & 30 & 32 & 28 & 31 & 33 \\
Parsley & 20 & 23 & 23 & 25 & 30 & 28 \\
Mint & 25 & 25 & 26 & 26 & 30 & 30 \\
Cinnamon & 22 & 24 & 33 & 26 & 28 & \\
\hline
\end{tabular}

Table (6) Antimicrobial activity of different essential oils on the isolated bacteria vs. Amoxicillin antibiotic.

\begin{tabular}{lcccccc}
\hline $\begin{array}{l}\text { Bacteria } \\
\text { OSE }\end{array}$ & $\begin{array}{c}\text { E. } \\
\text { coli }\end{array}$ & $\begin{array}{c}\text { Staph. } \\
\text { aureus }\end{array}$ & $\begin{array}{c}\text { Pseudomonas } \\
\text { sp. }\end{array}$ & $\begin{array}{c}\text { Streptococcus } \\
\text { sp. }\end{array}$ & $\begin{array}{c}\text { Klebsiella } \\
\text { sp. }\end{array}$ & $\begin{array}{c}\text { Candida } \\
\text { albicans }\end{array}$ \\
\hline Control & 14 & 15 & 14 & 12 & 23 & 17 \\
Onion & 16 & 12 & 21 & 17 & -12 & 20 \\
Garlic & 16 & 12 & 11 & 11 & 13 & 20 \\
Arugala & 18 & 13 & 14 & 15 & & 20 \\
Rosemary & 16 & 12 & 15 & 22 & 12 & 20 \\
Thyme & 20 & 12 & 18 & 22 & 15 & 20 \\
Parsley & 17 & 15 & 14 & 25 & 10 & 29 \\
Mint & 16 & 12 & 15 & 20 & & 22 \\
Cinnamon & 20 & 12 & 10 & 20 & & \\
\hline
\end{tabular}




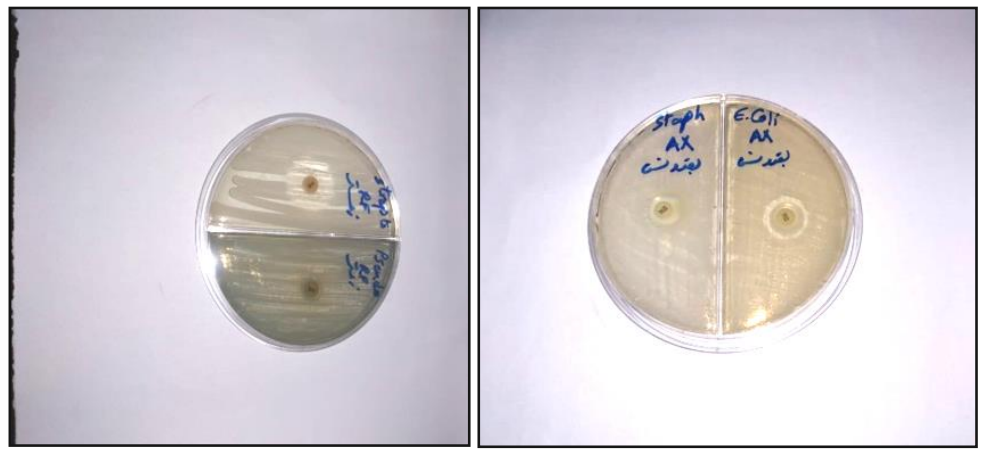

Sch (1) Sensitivity test of certain bacteria to essential oils.

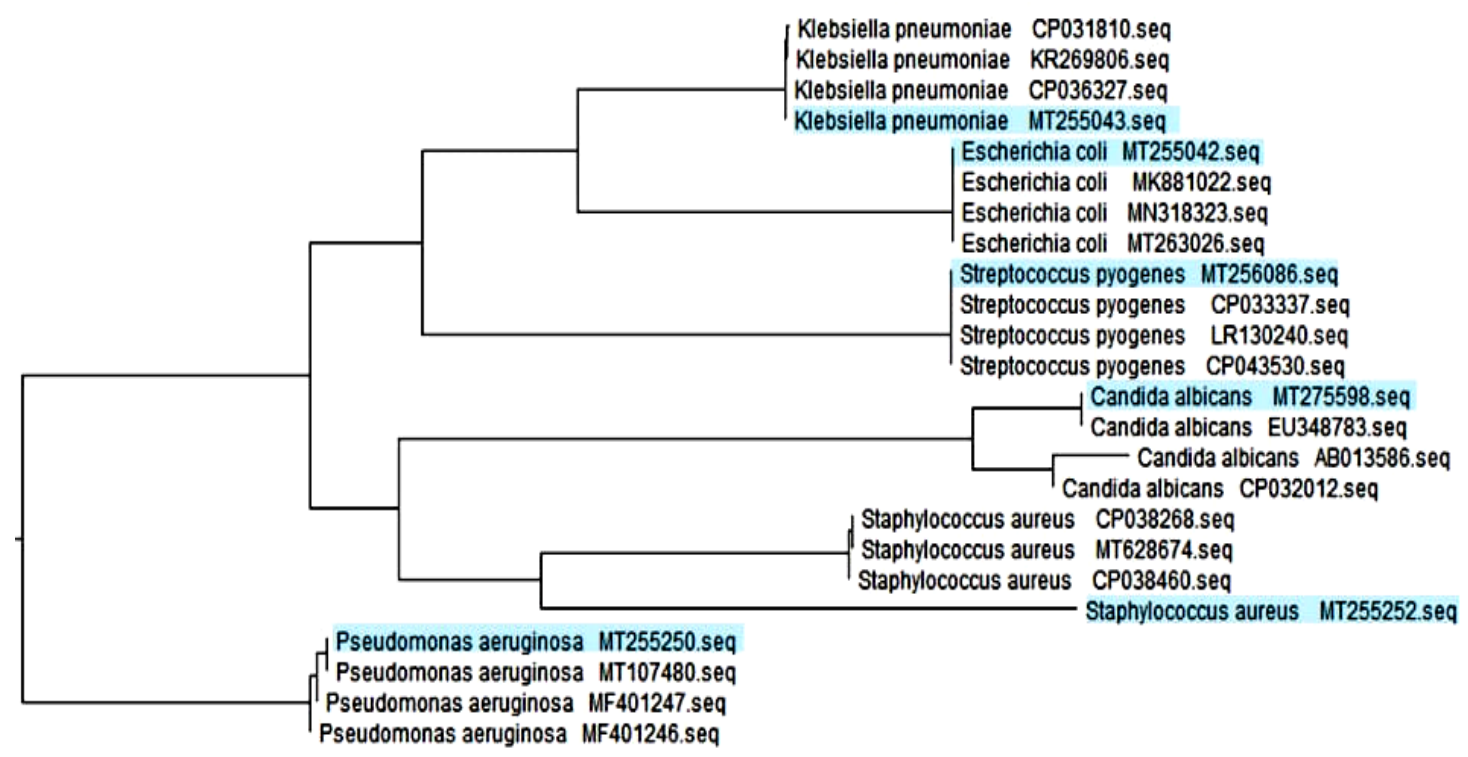

Fig (1) Phylogenetic tree shows the evolutionary relationships between the 16s rRNA sequences of the isolated acne bacteria with their bacterial concatenated nucleotide sequences of their 16s rRNA.

\section{6s rRNA gene sequencin2}

In the current study, BLASTn alignments and phylogenetic tree Fig (1) of the assembled 16s rRNA gene sequences showed similarities with the previously partially sequenced $16 \mathrm{~S}$ rRNA of Candida albicans strain, Escherichia coli, Klebsiella pneumoniae, Pseudomonas aeruginosa, Staphylococcus aureus and Streptococcus pyogenes on the NCBI website.

\section{Isolates Accession numbers}

Candida albicans strain, Escherichia coli, Klebsiella pneumoniae, Pseudomonas aeruginosa, Staphylococcus aureus and Streptococcus pyogenes were deposited in the Gene Bank database and were assigned the accession numbers MT275598, MT255042, MT255043, MT255250, MT255252 and MT256086 respectively .

\section{Conclusion and Recommendation}

The results of the present study describe the isolation of six different bacteria; Staphylococcus aureus, E. coli, Pseudomonas sp. Streptococcus sp., Klebsiella sp. Candida albicans from Egypt. The antibacterial effects of some medicinal plant oils were tested against the isolated bacteria, Parlesy and garlic oils were found to be rich sources for essential oils with many therapeutic uses. Both are considered good candidates to replace antibiotics in therapy.

\section{Discussion}

In the present study, we study the Interaction of Some Medical Oils with Antibiotics and Its Effect on Some Pathogenic Microorganisms. Antibiotic resistance is a global problem. Antibiotic resistant bacteria have reached a worrying stage all over the world, mainly in the developing countries [6]. Egypt is one of the countries that have less severe restrictions on antibiotic prescription [8].

It is very common to use essential oils in the treatment of most diseases, for instance skin infectious diseases. Furthermore, it is added as an active constituent in many topical formulations used for the treatment of cutaneous infections for 
controlling dandruff, acne, lice, herpes and other skin infections [5].

\section{References}

[1] N.A. Abdelmajeed, E.N. Danial, H.S. Ayad ,The effect of environmental stress on qualitative and quantitative essential oil of aromatic and medicinal plants. Archives Des Sciences, Vol. 66(4), PP. 100-120,2013.

[2] A.L.K. Abia, E .Ubomba-Jaswa, M.N.B. Momba High prevalence of multiple-antibiotic-resistant (MAR) Escherichia coli in river bed sediments of the Apies River, South Africa. Environmental Monitoring and Assessment, Vol. 187(10),PP. $652,2015$.

[3] A.N.M. Alamgir , Bioactive Compounds and Pharmaceutical Excipients Derived from Animals, Marine Organisms, Microorganisms, Minerals, Synthesized Compounds, and Pharmaceutical DrugsIn Therapeutic Use of Medicinal Plants and their Extracts,Vol.2,PP. 311-406,2018.

[4] A.J. Alanis, Resistance to antibiotics: are we in the post-antibiotic era? Archives of Medical Research,Vol.36(6), PP.697-705,2005.

[5] B. Ali, N.A. Al-Wabel, S. Shams, Essential oils used in aromatherapy: A systemic review. Asian Pacific Journal of Tropical Biomedicine, Vol.5(8),PP. 601-611,2015

[6] B. Ali, N.A. Al-Wabel, S. Shams, Essential oils used in aromatherapy: A systemic review. Asian Pacific Journal of Tropical Biomedicine,Vol.5(8), PP. 601-611,2015.

[7] M.M.J. Al-Obaidi, Z. Suhaili, M.N. MohdDesa, Genotyping Approaches for Identification and Characterization of Staphylococcus aureus. IntechOpen: London, Vol.25(5), PP.212225,2018

[8] K.R. Aneja, A textbook of Basic and Applied Microbiology; New Age International, Vol.60,
PP.425-435,2008.

[9] L. Ascensão, M.S. Pais ,The leaf capitate trichomes ofLeonotis leonurus: histochemistry, ultrastructure and secretion. Annals of Botany ,Vol. 81(2), PP. 263-271,1998.

[10]B. Aslam, W .Wang, M.I. Arshad, Antibiotic resistance: a rundown of a global crisis. Infection and Drug Resistance,Vol. 11, PP.1645,2018.

[11]F.M. Ausubel, Short protocols in molecular biology: a compendium of methods from current protocols in molecular biologyIn Short protocols in molecular biology: a compendium of methods from current protocols in molecular biology, Vol.67,PP. 210-230,1999

[12]F.M. Ausubel, Short protocols in molecular biology: a compendium of methods from current protocols in molecular biologyIn Short protocols in molecular biology: a compendium of methods from current protocols in molecular biology, Vol.30(8) PP. 230-245,1999

[13] J.A. Ayukekbong, M. Ntemgwa, A.N. Atabe ,The threat of antimicrobial resistance in developing countries: causes and control strategies. Antimicrobial Resistance \& Infection Control; 6(1): 47.

[14] M. Balouiri, M. Sadiki, S.K. Ibnsouda, Methods for in vitro evaluating antimicrobial activity: A review. Journal of Pharmaceutical Analysis, Vol.6(2), PP. 71-79,2016.

[15] M. Balouiri, M. Sadiki, S.K. Ibnsouda, Methods for in vitro evaluating antimicrobial activity: A review. Journal of Pharmaceutical Analysis; 6(2): 71-79,2016.

[16]P. Berche Louis Pasteur, from crystals of life to vaccination. Clinical Microbiology and Infection, Vol.18,PP. 1-6,2012.

[17]J. Bérdy, Thoughts and facts about antibiotics: where we are now and where we are heading. The Journal of Antibiotics, Vol. 65(8), PP. 385$395,2012$. 